KEY WORDS: Performance Assessment Lead Counterweights Lead Shielding

\title{
ANALYSIS OF DISPOSAL OF LEAD \\ IN THE E-AREA LOW-LEVEL WASTE FACILITY
}

\author{
Authors \\ James R. Cook \\ Elmer L. Wilhite \\ Westinghouse Savannah River Company \\ Savannah River Technology Center \\ Aiken, SC 29808
}

February 20, 2002

Westinghouse Savannah River Company

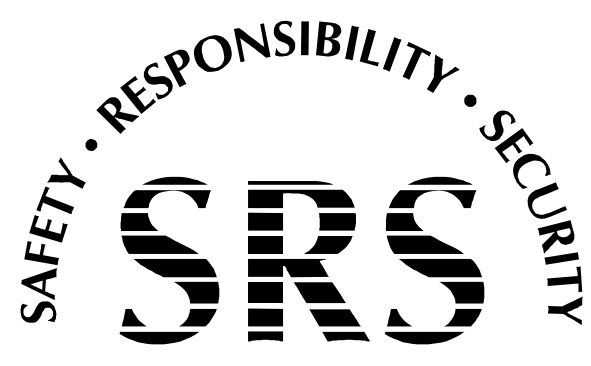


This document was prepared in conjunction with work accomplished under Contract No. DEAC09-96SR18500 with the U.S. Department of Energy.

\section{DISCLAIMER}

This report was prepared as an account of work sponsored by an agency of the United States Government. Neither the United States Government nor any agency thereof, nor any of their employees, makes any warranty, express or implied, or assumes any legal liability or responsibility for the accuracy, completeness, or usefulness of any information, apparatus, product or process disclosed, or represents that its use would not infringe privately owned rights. Reference herein to any specific commercial product, process or service by trade name, trademark, manufacturer, or otherwise does not necessarily constitute or imply its endorsement, recommendation, or favoring by the United States Government or any agency thereof. The views and opinions of authors expressed herein do not necessarily state or reflect those of the United States Government or any agency thereof.

This report has been reproduced directly from the best available copy.

Available for sale to the public, in paper, from: U.S. Department of Commerce, National Technical Information Service, 5285 Port Royal Road, Springfield, VA 22161

phone: (800) 553-6847

fax: (703) 605-6900

email: orders@ntis.fedworld.gov

online ordering: http://www.ntis.gov/support/index.html

Available electronically at http://www.osti.gov/bridge

Available for a processing fee to U.S. Department of Energy and its contractors, in paper, from: U.S. Department of Energy, Office of Scientific and Technical Information, P.O. Box 62, Oak Ridge, TN 37831-0062

phone: (865)576-8401

fax: (865)576-5728

email: reports@adonis.osti.gov 


\section{REVIEWS AND APPROVALS}

\section{Author}

James R. Cook, Author

Date

Waste Disposal and Environmental Development

Elmer L. Wilhite, Author

Date

Waste Disposal and Environmental Development

\section{SRTC Review/Approvals}

Daniel I. Kaplan, Reviewer

Date

Waste Processing Technology

W. E. Stevens, Level 3

Date

Waste Processing Technology

B. T. Butcher, Level 4

Date

Waste Disposal and Environmental Development

\section{Solid Waste Division Approval}

W. T. Goldston

Date

Solid Waste Division 


\section{Executive Summary}

SRS representatives met with SCDHEC on September 19, 2000 to discuss an SRS proposal for the future disposal of lead-bearing radioactively contaminated equipment. SRS followed up with a letter to SCDHEC on October 25, 2000 documenting the meeting and requesting approval to dispose of lead bearing equipment based in part on evaluations of the effect of lead disposal on the environment developed to support closure decisions for the Old Radioactive Waste Burial Ground in E-Area.

On April 6, 2001 the South Carolina Department of Health and Environmental Control (SCDHEC) issued a letter approving the disposal of SRS generated waste equipment with lead shielding or counterweights at the SRS Low-Level Waste Facility. The quantity of lead was limited to 100,000 pounds.

SRTC was asked to conduct an additional modeling study to determine the impact of lead on groundwater of this disposal action and to assist in developing Waste Acceptance Criteria (WAC). The simulations analyzed were direct trench disposal (i.e., trench disposal with no grout) and trench disposal as "Components in Grout."

The calculated groundwater concentrations for lead depend greatly on the time of compliance selected, varying from no impact for a time of compliance of 1,000 years (the time required by DOE for low-level waste disposal performance assessments) to one hundred times the action level if the time of the maximum concentration (several tens of thousands of years) is used. The calculated groundwater concentrations at 10,000 years (the compliance time used in the SRS E-Area Disposal Facility PA) are millions of times less than the action level. There is no current Maximum Contaminant Level (MCL) for lead. SRS uses an action level of $0.015 \mathrm{mg} / \mathrm{L}$ as a compliance measure.

Lead disposal limits are developed for trench disposal, Components in Grout disposal, Low Activity Waste Vault disposal and Intermediate Level Vault disposal. All of these limits are much greater than the current administrative limit of 100,000 pounds.

\section{Modeling Approach}

The groundwater-to-well pathway was modeled, with the only exposure pathway being drinking the well water. PATHRAE-HAZ (Shuman and Merrell, 1998) was modified in June of 1998 to allow step-wise changes in release rates. Therefore, both capped and uncapped periods are accounted for in each disposal scenario. A sorption coefficient $\left(\mathrm{K}_{\mathrm{d}}\right)$ for lead of $270 \mathrm{ml} / \mathrm{g}$ was used for both horizontal and vertical transport in the aquifer and $500 \mathrm{ml} / \mathrm{g}$ in cementitious material.

The effects of $\mathrm{pH}$ dependent solubility limits were included in this analysis. The results of a study of the effects of a cementitious environment on the solubility of lead (Kaplan and Myers, 2001) were used. Figure 1 shows the change in lead solubility as a function of time from this report.

Three conservative assumptions have been made in this work and the lead solubility work on which it is based (Kaplan and Meyers, 2001):

1. the metallic lead $\left(\mathrm{Pb}^{0}\right)$ disposed as "Components in Grout" was assumed to instantly convert to more soluble $\mathrm{Pb}^{++}$,

2. the steel encapsulating the lead-bearing waste was assumed not present, and

3. mineral rime coatings expected to form on the lead and to protect it from further contact with water were assumed not present. 
An initial inventory of 100,000 pounds (SCDHEC, 2001) of lead was used in each simulation. Several runs were made to calculate the concentrations at various intervals from 0 to 70,000 years. Each simulation was also run using the peak finding option to find the time and magnitude of the maximum lead concentration at a well 100 meters from the waste. The simulation was run again at times directly before and after the peak, to better determine the release behavior. Each scenario is described in further detail below and is also summarized in Tables 1 and 2 .

\section{Direct Trench Disposal}

The dimensions used for the direct trench disposal scenario are $200 \mathrm{~m}$ by $45 \mathrm{~m}$. These dimensions account for one set of five trenches, each trench being $200 \mathrm{~m}$ long, $6 \mathrm{~m}$ wide, and $6 \mathrm{~m}$ deep with about 3$\mathrm{m}$ of undisturbed soil separating the trenches. The trenches are filled with $4.8 \mathrm{~m}$ of waste and $1.2 \mathrm{~m}$ of a clean soil cover. The volume of waste disposed in five trenches is equal to $28,800 \mathrm{~m}^{3}$. Three release steps are used for the trench scenario; these include an initial uncapped period from 0 to 25 years, a capped period from 25 to 125 years, and a failed cap after 125 years. The trench disposal scenario accounts for advection only, and no solubility dependent release rates are calculated (i.e., no cementitious materials are assumed present).

\section{$\underline{\text { Components in Grout }}$}

This scenario is similar to direct trench disposal in that it also accounts for one set of five trenches of dimension $200 \mathrm{~m}$ by $45 \mathrm{~m}$. The "Components in Grout" scenario has the same values for waste thickness, soil cover thickness, and waste volume: $4.8 \mathrm{~m}, 1.2 \mathrm{~m}$, and $28,800 \mathrm{~m}^{3}$, respectively, as the direct trench disposal case. Eight release steps are used for the "Components in Grout" scenario. These include changes due to the condition of the closure cap, an initial uncapped period ( $0-25$ years), a capped period (25-300 years), a failed cap after 300 years, and the effects of the changes in the properties of the grout as it ages. The effective leach rates for each step are given in Table 3. The advection-based fractional leach rates for $40 \mathrm{~cm} /$ year infiltration (i.e., the uncapped and failed cap periods) and $4 \mathrm{~cm} /$ year infiltration (i.e., the intact cap period) are $1.0 \times 10^{-4}$ and $1.09 \times 10^{-5}$ per year, respectively. When the solubility limit is sufficiently low, it determines the leach rate. This scenario accounts for the chemical effects of the grout used in the disposal method, assuming that the water has equilibrated with cementitious material before contacting the lead, and the longer durability of the cap. This scenario has not accounted for the lower hydraulic conductivity of the grouted waste. 


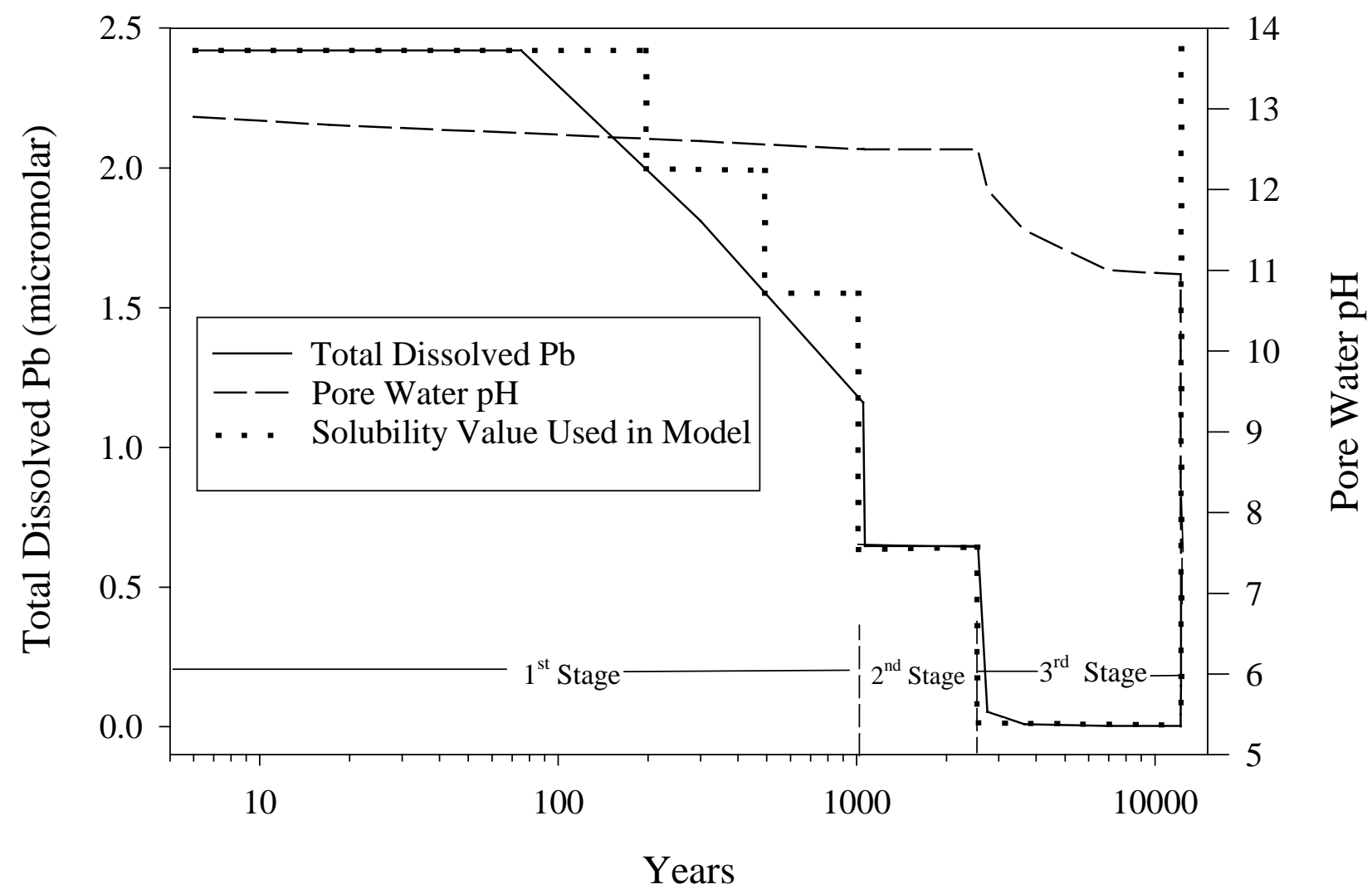

Figure 1. Time dependent lead solubility (adapted from Kaplan and Meyers, 2001) 
Table 1. Data Sheet for Direct Trench Disposal Model

\begin{tabular}{|c|c|c|c|}
\hline Variable & Property & Value & Source \\
\hline $\mathrm{A}(\mathrm{I})$ & Title of run & Trench - No Steel & \\
\hline NTIME & Number of times analyzed & 10 per run & Model limitation \\
\hline NISO & Number of contaminants & 1 & \\
\hline NNP & Number of pathways & 1 & \\
\hline $\mathrm{NNP}(\mathrm{J})$ & Pathway index & 2 & groundwater to well \\
\hline $\mathrm{JUF}(\mathrm{J})$ & Water use index & 3 & well water used only for drinking \\
\hline TIMOP & Time of operations & 0 & Assumption \\
\hline XLP & Length of facility & $200 \mathrm{~m}$ & EAV PA (WSRC 2000) \\
\hline WIDTH & Width of facility & $45 \mathrm{~m}$ & EAV PA (WSRC 2000) \\
\hline ARHO & Density of aquifer & $1,600 \mathrm{~kg} / \mathrm{m}^{3}$ & EAV PA (WSRC 2000) \\
\hline ALDIS & Longitudinal dispersivity & $10 \mathrm{~m}$ & Assumption \\
\hline DY & Transverse dispersion & 0 & Assumption \\
\hline $\mathrm{DZ}$ & Vertical dispersion & 0 & Assumption \\
\hline SS & Fraction of saturation & 0.635 & Calculated in Code \\
\hline$\overline{S R}$ & Residual saturation & 0.1 & EAV PA (WSRC 2000) \\
\hline $\mathrm{PV}$ & Sat. conductivity of vertical zone & $3.2 \mathrm{~m} / \mathrm{yr}$ & EAV PA (WSRC 2000) \\
\hline NM & No. of mesh points & 20 & PATHRAE Suggestion \\
\hline NMY & No. mesh points y & 5 & PATHRAE Suggestion \\
\hline NMZ & No. mesh points $\mathrm{z}$ & 5 & PATHRAE Suggestion \\
\hline $\mathrm{XCT}$ & Cover thickness & $1.2 \mathrm{~m}$ & EAV PA (WSRC 2000) \\
\hline XWT & Waste thickness & $4.8 \mathrm{~m}$ & EAV PA (WSRC 2000) \\
\hline TWV & Waste volume & $28,800 \mathrm{~m}^{3}$ & LxWxT \\
\hline $\mathrm{XW}$ & Distance to well & $1 \mathrm{~m}$ and $100 \mathrm{~m}$ & Assumption \\
\hline YW & Well distance off centerline & $0 \mathrm{~m}$ & Assumption \\
\hline $\mathrm{RHO}$ & Density of waste & $1,600 \mathrm{~kg} / \mathrm{m}^{3}$ & EAV PA (WSRC 2000) \\
\hline CANLIFE & Waste container lifetime & $0 \mathrm{yr}$ & Assumption \\
\hline XPERC & Water infiltration through waste & $0.4 \mathrm{~m} / \mathrm{yr}$ & EAV PA (WSRC 2000) \\
\hline VA & Horizontal velocity of aquifer & $10 \mathrm{~m} / \mathrm{yr}$ & \\
\hline PORA & Porosity of aquifer & 0.42 & EAV PA (WSRC 2000) \\
\hline XAQD & Distance from waste to aquifer & $8 \mathrm{~m}$ & EGG DATA \\
\hline $\mathrm{XVV}$ & Vertical velocity in unsaturated zone & & Calculated in code \\
\hline XLC & Well screen length & $6.0 \mathrm{~m}$ & Thickness of top node \\
\hline XALE & Surface erosion rate & $2.0 \times 10^{-3} \mathrm{~m} / \mathrm{yr}$ & EAV PA (WSRC 2000) \\
\hline RUNF & Annual precipitation runoff rate & $0.4 \mathrm{~m} / \mathrm{yr}$ & EAV PA (WSRC 2000) \\
\hline PORU & Porosity of unsaturated zone & 0.42 & EAV PA (WSRC 2000) \\
\hline NSEG & Number steps in release function & 3 & EAV PA (WSRC 2000) \\
\hline ST(I) & Start time for each NSEG step & $0,25,125$ & EAV PA (WSRC 2000) \\
\hline $\begin{array}{l}\text { QINPUT } \\
(\mathrm{KK}, \mathrm{M})\end{array}$ & Amount of chemical present at time $\mathrm{T}(1)$ & $\begin{array}{l}100,000 \mathrm{lb} \\
45,360 \mathrm{~kg}\end{array}$ & Disposal limit \\
\hline SOL (KK) & $\begin{array}{l}\text { Chemical solubility in water percolating } \\
\text { through waste }\end{array}$ & 0 & No solubility limit \\
\hline XKD & Partition Coefficient & $270 \mathrm{ml} / \mathrm{g}$ & Sheppard \& Thibault 1990 \\
\hline SINFL & Watershed infiltration rate & $0.38 \mathrm{~m} / \mathrm{yr}$ & EAV PA (WSRC 2000) \\
\hline PORS & Porosity of soil & 0.42 & EAV PA (WSRC 2000) \\
\hline BDENS & Bulk density of soil & $1.6 \mathrm{~g} / \mathrm{cm}^{3}$ & EAV PA (WSRC 2000) \\
\hline XLLI & Leach constant & Based on soil $\mathrm{K}_{\mathrm{d}}$ & Baes \& Sharp 1983 \\
\hline
\end{tabular}


Table 2. Data Sheet for Components in Grout Model

\begin{tabular}{|c|c|c|c|}
\hline Variable & Property & Value & Source \\
\hline $\mathrm{A}(\mathrm{I})$ & Title of run & $\begin{array}{l}\text { Components in Grout with } \\
\text { Solubility Limit, No Steel }\end{array}$ & \\
\hline NTIME & Number of times analyzed & 10 per run & Model limitation \\
\hline NISO & Number of contaminants & 1 & \\
\hline NNP & Number of pathways & 1 & \\
\hline $\mathrm{NNP}(J)$ & Pathway index & 2 & groundwater to well \\
\hline $\mathrm{JUF}(\mathrm{J})$ & Water use index & 3 & well water used only for drinking \\
\hline TIMOP & Time of operations & 0 & Assumption \\
\hline XLP & Length of facility & $200 \mathrm{~m}$ & EAV PA (WSRC 2000) \\
\hline WIDTH & Width of facility & $45 \mathrm{~m}$ & EAV PA (WSRC 2000) \\
\hline $\mathrm{ARHO}$ & Density of aquifer & $1,600 \mathrm{~kg} / \mathrm{m}^{3}$ & EAV PA (WSRC 2000) \\
\hline ALDIS & Longitudinal dispersivity & $10 \mathrm{~m}$ & Assumption \\
\hline DY & Transverse dispersion & 0 & Assumption \\
\hline $\mathrm{DZ}$ & Vertical dispersion & 0 & Assumption \\
\hline SS & Fraction of saturation & 0.635 & Calculated in Code \\
\hline$\overline{S R}$ & Residual saturation & 0.1 & EAV PA (WSRC 2000) \\
\hline PV & Sat. conductivity of vertical zone & $3.2 \mathrm{~m} / \mathrm{yr}$ & EAV PA (WSRC 2000) \\
\hline NM & No. of mesh points & 20 & PATHRAE Suggestion \\
\hline NMY & No. mesh points $\mathrm{y}$ & 5 & PATHRAE Suggestion \\
\hline NMZ & No. mesh points $\mathrm{Z}$ & 5 & PATHRAE Suggestion \\
\hline $\mathrm{XCT}$ & Cover thickness & $1.2 \mathrm{~m}$ & EAV PA (WSRC 2000) \\
\hline XWT & Waste thickness & $4.8 \mathrm{~m}$ & EAV PA (WSRC 2000) \\
\hline TWV & Waste volume & $28,800 \mathrm{~m}^{3}$ & LxWxT \\
\hline $\mathrm{XW}$ & Distance to well & $1 \mathrm{~m}$ and $100 \mathrm{~m}$ & Assumption \\
\hline YW & Well distance off centerline & $0 \mathrm{~m}$ & Assumption \\
\hline RHO & Density of waste & $1,600 \mathrm{~kg} / \mathrm{m}^{3}$ & EAV PA (WSRC 2000) \\
\hline CANLIFE & Waste container lifetime & $0 \mathrm{yr}$ & Assumption \\
\hline XPERC & Water infiltration through waste & $0.4 \mathrm{~m} / \mathrm{yr}$ & EAV PA (WSRC 2000) \\
\hline VA & Horizontal velocity of aquifer & $10 \mathrm{~m} / \mathrm{yr}$ & EAV PA (WSRC 2000) \\
\hline PORA & Porosity of aquifer & 0.42 & EAV PA (WSRC 2000) \\
\hline XAQD & Distance from waste to aquifer & $8 \mathrm{~m}$ & EGG DATA \\
\hline XVV & Vertical velocity in unsaturated zone & Calculated in code & \\
\hline $\mathrm{XLC}$ & Well screen length & $6.0 \mathrm{~m}$ & Thickness of top node \\
\hline XALE & Surface erosion rate & $2.0 \times 10^{-3} \mathrm{~m} / \mathrm{yr}$ & EAV PA (WSRC 2000) \\
\hline RUNF & Precipitation runoff rate & $0.4 \mathrm{~m} / \mathrm{yr}$ & EAV PA (WSRC 2000) \\
\hline PORU & Porosity of unsaturated zone & 0.42 & EAV PA (WSRC 2000) \\
\hline NSEG & Number steps in release function & 8 & This report \\
\hline ST(I) & Start time for each NSEG step & $\begin{array}{l}0,25,200,30,500,1000, \\
2500 \text { and } 12,000 \text { years }\end{array}$ & $\begin{array}{l}\text { EAV PA (WSRC 2000) } \\
\text { Kaplan and Myers 2000 }\end{array}$ \\
\hline $\begin{array}{l}\text { QINPUT } \\
(\mathrm{KK}, \mathrm{M})\end{array}$ & Amount of chemical present at time $\mathrm{T}(1)$ & $\begin{array}{l}100,000 \mathrm{lb} \\
45,360 \mathrm{~kg}\end{array}$ & Disposal limit \\
\hline SOL (KK) & $\begin{array}{l}\text { Chemical solubility in water percolating } \\
\text { through waste }\end{array}$ & Time dependent & Kaplan and Myers 2000 \\
\hline $\mathrm{XKD}$ & Partition Coefficient in aquifer & $270 \mathrm{ml} / \mathrm{g}$ & Sheppard \& Thibault 1990 \\
\hline XKD & Partition Coefficient in concrete & $500 \mathrm{ml} / \mathrm{g}$ & Bradbury \& Sarott 1995 \\
\hline SINFL & Watershed infiltration rate & $0.38 \mathrm{~m} / \mathrm{yr}$ & EAV PA (WSRC 2000) \\
\hline PORS & Porosity of soil & 0.42 & EAV PA (WSRC 2000) \\
\hline BDENS & Bulk density of soil & $1.6 \mathrm{~g} / \mathrm{cm}^{3}$ & EAV PA (WSRC 2000) \\
\hline XLLI & Leach constant & $\begin{array}{l}\text { Based on concrete } K_{d} \text { or } \\
\text { solubility }\end{array}$ & $\begin{array}{l}\text { Bradbury \& Sarott } 1995 \\
\text { Kaplan and Myers } 2000\end{array}$ \\
\hline
\end{tabular}




\begin{tabular}{|l|l|l|l|}
\hline \multicolumn{5}{|l|}{ Table 3. Leach rates used in the "Components in Grout" model } \\
\hline Time, years & Lead Solubility, mg/l & Infiltration Rate, cm/yr & Leach Rate, $\mathrm{yr}^{-1}$ \\
\hline $0-25$ & $5.0 \times 10^{-1}$ & 40 & $4.0 \times 10^{-5}$ \\
\hline $25-200$ & $5.0 \times 10^{-1}$ & 4 & $1.0 \times 10^{-5}$ \\
\hline $200-300$ & $3.3 \times 10^{-1}$ & 4 & $1.0 \times 10^{-5}$ \\
\hline $300-500$ & $3.3 \times 10^{-1}$ & 40 & $2.6 \times 10^{-5}$ \\
\hline $500-1,000$ & $3.1 \times 10^{-1}$ & 40 & $2.5 \times 10^{-5}$ \\
\hline $1000-2,500$ & $1.5 \times 10^{-1}$ & 40 & $1.2 \times 10^{-5}$ \\
\hline $2,500-12,000$ & $5.6 \times 10^{-4}$ & 40 & $4.4 \times 10^{-8}$ \\
\hline$>12,000$ & No solubility limit & 40 & $1.9 \times 10^{-4}$ \\
\hline
\end{tabular}

\section{Modeling Results}

Each simulation was run using both the peak finding option and the option which calculates concentrations at specific times. The lead concentration in a groundwater well 100-m from the waste was calculated by PATHRAE-HAZ for each given time. These data were used to produce a concentration versus time plot for each scenario (Figures 2 and 3). The peak times for direct trench disposal and "Components in Grout" scenarios are 22,426 years and 34,288 years, respectively. The results for peak concentrations are given in Table 4.

\begin{tabular}{|l|c|c|}
\hline Table 4. Peak groundwater concentration results based on disposal of 100,000 lb of lead \\
\hline Disposal Unit & Time of Peak (years) & Peak Concentration (mg/L) \\
\hline Trench & 22,426 & 0.99 \\
\hline Components in Grout & 34,288 & 0.96 \\
\hline
\end{tabular}

Other times of potential interest are 1,000 years (i.e., the time required by DOE for low-level waste disposal performance assessments) and 10,000 years (i.e., the compliance time used in the SRS E-Area Disposal Facility PA). The groundwater concentrations for these times for each of the disposal units are shown in Table 5.

\begin{tabular}{|c|c|c|}
\hline Disposal Unit & $\begin{array}{c}\text { Concentration at } 1,000 \text { years } \\
(\mathrm{mg} / \mathrm{L})\end{array}$ & $\begin{array}{c}\text { Concentration at 10,000 years } \\
(\mathrm{mg} / \mathrm{L})\end{array}$ \\
\hline Trench & 0 & $4.0 \times 10^{-9}$ \\
\hline Components in Grout & 0 & $8.2 \times 10^{-10}$ \\
\hline
\end{tabular}




\section{Impact of Steel Macroencapsulation}

The model results show that for typical times of compliance, 1,000 and 10,000 years, either method of disposal will meet a performance objective of groundwater concentrations less than the SRS action level of $0.015 \mathrm{mg} / \mathrm{l}$. Lead shielding and counterweights are encased in welded steel jackets which will take some time to corrode before the lead is available for leaching and transport. The effect of macroencapsulation in steel was not simulated in this study.

However, to provide a qualitative assessment of the impact of the steel encapsulation on the migration of lead to groundwater, corrosion rates of steel were considered. A study done for the Tritium Extraction Facility performance assessment (Chandler, 1998) looked at corrosion rates of stainless and carbon steel as a function of $\mathrm{pH}$. The results of that study that pertain to this work are given in Table 6 .

\begin{tabular}{|l|l|l|l|}
\hline \multicolumn{5}{|c|}{ Table 6. Time in years to corrode 0.25 inches of stainless and carbon steels } \\
\hline & $\mathrm{pH}=12$ & $\mathrm{pH}=8-10$ & $\mathrm{pH}=4.5-5$ \\
\hline Stainless Steel & $2.5 \times 10^{6}$ & $2.5 \times 10^{6}$ & $2.5 \times 10^{6}$ \\
\hline Carbon Steel & $9.1 \times 10^{4}$ & $6.4 \times 10^{1}$ & $1.3 \times 10^{2}$ \\
\hline
\end{tabular}

The effect of the encasing steel in the CIG scenario would be to shield the lead from the initial, high $\mathrm{pH}$, pore fluid. Thus, the magnitude of the peak would be reduced in proportion to the reduction in lead solubility (Figure 1) and would be delayed by a time interval equal to the appropriate value in Table 6. For the direct trench disposal scenario, the effect would be essentially the same for stainless steel. For carbon steel, the effect would be to delay the release and to suppress the lead concentrations to some extent, but not as much as for stainless steel.

\section{Output Files}

The PATHRAE output files used to calculate the peak concentrations for each disposal unit are included as Attachments 1 and 2.

\section{Interpretation of Results}

For direct trench disposal (i.e., no grout), the modeling results shown in Figure 2 and Tables 4 and 5 show very low lead impacts on groundwater until about 12,000 years after disposal. Since the steel encapsulating the lead is neglected in the analysis, these results are very conservative. With stainless steel encapsulation, the usual material for encapsulating lead on equipment, assuming one-quarter inch thickness, contact of the lead with infiltrating water will be delayed for about two million years. Thus, the development of lead concentrations in groundwater, as depicted in Figure 2, would be delayed by about two million years. If carbon steel were used to encapsulate the lead, the delay in lead migration to the groundwater would be about 130 years. The groundwater concentration results developed in this study can be used to develop a very conservative lead inventory limit for trench disposal. For a 1,000year time of compliance, there would be no limit (i.e., any quantity of lead could be disposed) since the groundwater concentration at 1,000 years is zero. For a 10,000-year time of compliance, the lead disposal limit would be $3.8 \times 10^{11}$ pounds. If the maximum groundwater concentration, regardless of time (i.e., the peak value), were used, the lead disposal limit would be $1.5 \times 10^{3}$ pounds.

For disposal as Components in Grout (i.e., encapsulated in cementitious material), the results shown in Figure 3 and Tables 4 and 5 show very low lead impacts on groundwater until about 15,000 years after disposal. Since the steel encapsulating the lead is neglected in the analysis, these results are very conservative. With stainless steel encapsulation, the usual material for encapsulating lead on equipment, 
assuming one-quarter inch thickness, contact of the lead with infiltrating water will be delayed for about two million years. Thus, the development of lead concentrations in groundwater, as depicted in Figure 2, would be delayed by about two million years and the initial peak, which is caused by the high lead solubility at high $\mathrm{pH}$, would disappear. If carbon steel were used to encapsulate the lead, the delay in lead migration to the groundwater would be about 2,000 years, the time required for the $\mathrm{pH}$ to decrease to about 5. The initial peak, which is caused by the high lead solubility at high $\mathrm{pH}$, would disappear. The groundwater concentration results developed in this study can be used to develop a very conservative lead inventory limit for CIG disposal. For a 1,000-year time of compliance, there would be no limit (i.e., any quantity of lead could be disposed) since the groundwater concentration at 1,000 years is zero. For a 10,000 -year time of compliance, the lead disposal limit would be $1.8 \times 10^{12}$ pounds. If the maximum groundwater concentration, regardless of time (i.e., the peak value), were used, the lead disposal limit would be $1.6 \times 10^{3}$ pounds.

The results for CIG disposal also provide a conservative representation of lead migration to groundwater from the E-Area Disposal Facility (EADF) vault units (i.e., Low Activity Waste Vault and Intermediate Level Vault). Since this study only considered the impact of the chemical properties of the grout, and both of the EADF vault units will provide at least as much chemical control, limits developed from the CIG results will conservatively bound the impacts from lead emplacement in the vaults.

\section{Lead Disposal Limits}

For consistency with limits developed from the EADF PA (WSRC 2000), the lead limits developed in this study for a 10,000-year time of compliance are appropriate. These limits are shown in Table 7. All are much greater than the current administrative limit of 100,000 pounds.

\begin{tabular}{|c|c|}
\hline $\begin{array}{l}\text { Table 7. Lead Disposal Limits For a 10,000-year } \\
\text { time of compliance }\end{array}$ & \\
\hline Disposal Unit & Lead Limit, pounds \\
\hline Trench & $3.8 \times 10^{11}$ \\
\hline CIG & $1.8 \times 10^{12}$ \\
\hline LAW Vault & $1.8 \times 10^{12}$ \\
\hline IL Vault & $1.8 \times 10^{12}$ \\
\hline
\end{tabular}




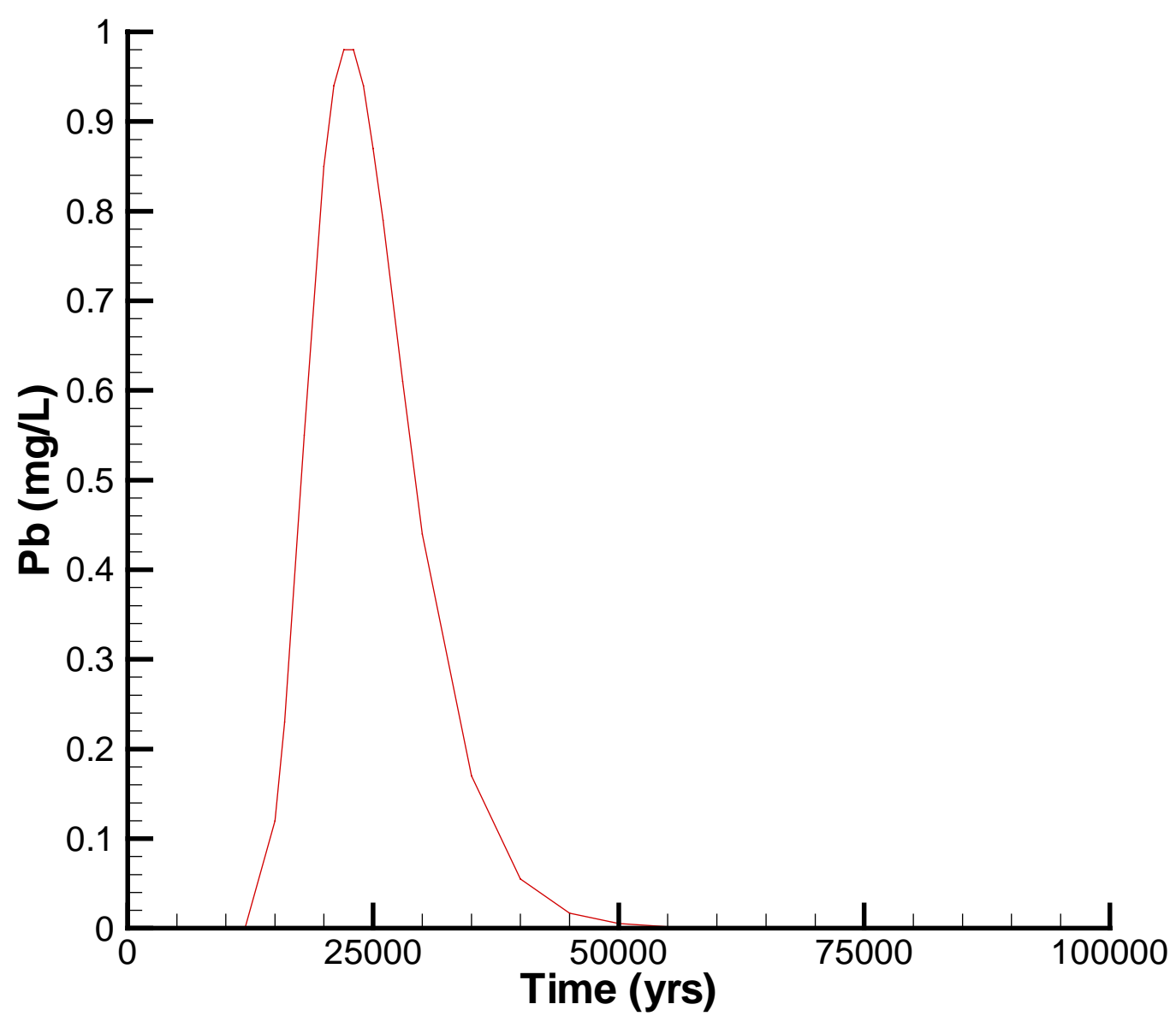

Figure 2. Time versus groundwater concentration of lead at $100 \mathrm{~m}$ well for trench disposal of $100,000 \mathrm{lb}$ of lead waste 


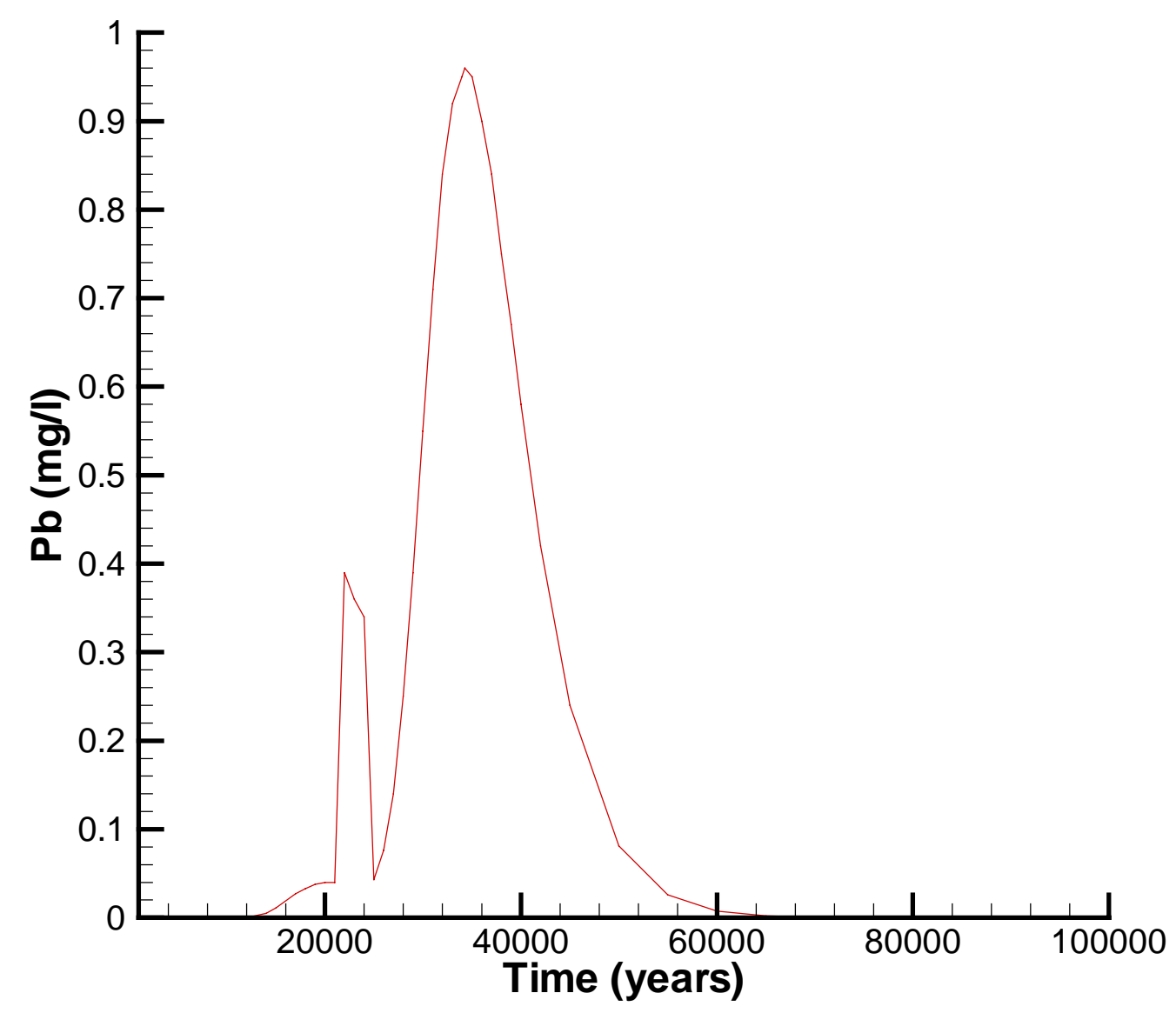

Figure 3. Time versus groundwater concentration of lead at $100 \mathrm{~m}$ well for "Components in Grout" disposal of $100,000 \mathrm{lb}$ of lead waste 


\section{References}

Baes, C. F. III, and R. D. Sharp. 1983. A Proposal for Estimation of Soil Leaching and Leaching Constants for Use in Assessment Models. J. Environ. Qual., 12:17.

Bradbury, M. H. and F. A. Sarott. 1995. Sorption Databases for the Cementitious Near-Field of a L/ILW Repository for Performance Assessment, Paul Scherrer Institut, Villigen.

Chandler, G. T. 1998. Corrosion Evaluation of Accelerator Production of Tritium and Tritium Extraction Facility Low-Level Waste and Disposal Boxes in the E-Area Vaults. SRT-MTS-98-2028, Westinghouse Savannah River Company, Aiken, SC.

Kaplan, Daniel I. and, James L Meyers. 2001. Long-Term Dynamics of Lead Solubility in a Cementitious Groundwater Environment, WSRC-TR-2000-00416, Westinghouse Savannah River Company, Aiken, SC.

Sheppard, M. I., and D. H. Thibault. 1990. Default Soil Solid/Liquid Partition Coefficients, Kds, for Four Major Soil Types: A Compendium. Health Physics, 59:471-482.

Shuman, R. and G. Merrell. 1998. The PATHRAE-HAZ Performance Assessment Code for the Land Disposal of Hazardous Chemical Wastes, Version 3.0. Rogers \& Associates Engineering Corporation, Salt Lake City, UT.

SCDHEC. 2001. Letter to J. V. Odum, Re Lead Disposal, April 6. 2001.

WSRC. 2000. Radiological Performance Assessment for the E-Area Low-Level Waste Facility,. WSRCRP-94-218, Rev. 1, Westinghouse Savannah River Company, Aiken, SC. 
Attachments 1 - 2

\section{PATHRAE OUTPUT FILES}


RESIDUAL SOIL SATURATION

PERMEABILITY OF VERTICAL ZONE (M/YR)

SOIL NUMBER

POROSITY OF AQUIFER

POROSITY OF UNSATURATED ZONE

DISTANCE FROM AQUIFER TO WASTE (M)

AVERAGE VERTICAL GROUNDWATER VELOCITY (M/YR)

HORIZONTAL VELOCITY OF AQUIFER (M/YR)

LENGTH OF PERFORATED WELL CASING (M)

SURFACE EROSION RATE (M/YR)

LEACH RATE SCALING FACTOR

ANNUAL RUNOFF OF PRECIPITATION (M)
.100

3.20

.250

.42

.42

8.0

$1.50 \mathrm{E}+00$

$1.00 \mathrm{E}+01$

6.000

$2.000 \mathrm{E}-03$

$1.000 \mathrm{E}+00$

4. $00 \mathrm{E}-01$

\begin{tabular}{|c|c|c|c|c|c|}
\hline CONTAMINANT & & $\begin{array}{c}\text { FACTORS } \\
\text { (KG-DAY/MG) }\end{array}$ & $\begin{array}{c}\text { ADLUAB } \\
\text { INTAKES } \\
\text { (MG/KG-DAY) }\end{array}$ & $\begin{array}{c}\text { HALF } \\
\text { LIFE (YR) }\end{array}$ & \\
\hline Lead & & $0.000 \mathrm{E}+00$ & $4.200 \mathrm{E}-04$ & $1.000 \mathrm{E}+10$ & \\
\hline CONTAMINANT & & $\begin{array}{l}\text { VOLATILITY } \\
\text { FRACTION }\end{array}$ & $\begin{array}{c}\text { VAPORIZATION } \\
\text { RATE } \\
(1 / \mathrm{S})\end{array}$ & $\begin{array}{c}\text { SKIN } \\
\text { ABSORPTION } \\
(\mathrm{M} / \mathrm{HR})\end{array}$ & \\
\hline Lead & & $0.000 \mathrm{E}+00$ & $0.000 \mathrm{E}+00$ & $0.000 \mathrm{E}+00$ & \\
\hline CONTAMINANT & SEG & $\begin{array}{c}\text { SEGMENT START } \\
(\mathrm{YR})\end{array}$ & $\begin{array}{c}\text { WASTE } \\
\text { DIFFUSION } \\
\text { COEF. } \quad(\text { CM2/S })\end{array}$ & $\begin{array}{c}\text { CONCRETE } \\
\text { DIFFUSION } \\
\text { COEF. } \quad(\text { CM2 } / \mathrm{S})\end{array}$ & \\
\hline $\begin{array}{l}\text { Lead } \\
\text { Lead } \\
\text { Lead } \\
\text { Lead } \\
\text { Lead } \\
\text { Lead } \\
\text { Lead } \\
\text { Lead }\end{array}$ & $\begin{array}{l}1 \\
2 \\
3 \\
4 \\
5 \\
6 \\
7 \\
8\end{array}$ & $\begin{array}{l}0.000 \mathrm{E}+00 \\
2.500 \mathrm{E}+01 \\
2.000 \mathrm{E}+02 \\
3.000 \mathrm{E}+02 \\
5.000 \mathrm{E}+02 \\
1.000 \mathrm{E}+03 \\
2.500 \mathrm{E}+03 \\
1.200 \mathrm{E}+04\end{array}$ & & & \\
\hline CONTAMINANT & SEG & $\begin{array}{l}\text { INPUT LEACH } \\
(1 / \text { YR })\end{array}$ & $\begin{array}{l}\text { FINAL LEACH } \\
(1 / \text { YR })\end{array}$ & $\begin{array}{l}\text { SOLUBILITY } \\
(\mathrm{MG} / \mathrm{L})\end{array}$ & $\begin{array}{c}\text { INITIAL } \\
\text { INVENTORY } \\
(\mathrm{KG})\end{array}$ \\
\hline $\begin{array}{l}\text { Lead } \\
\text { Lead } \\
\text { Lead } \\
\text { Lead } \\
\text { Lead } \\
\text { Lead } \\
\text { Lead } \\
\text { Lead }\end{array}$ & $\begin{array}{l}1 \\
2 \\
3 \\
4 \\
5 \\
6 \\
7 \\
8\end{array}$ & $\begin{array}{l}4.000 \mathrm{E}-05 \\
1.000 \mathrm{E}-05 \\
1.000 \mathrm{E}-05 \\
2.600 \mathrm{E}-05 \\
2.500 \mathrm{E}-05 \\
1.200 \mathrm{E}-05 \\
4.400 \mathrm{E}-08 \\
1.900 \mathrm{E}-04\end{array}$ & $\begin{array}{l}4.000 \mathrm{E}-05 \\
1.000 \mathrm{E}-05 \\
1.000 \mathrm{E}-05 \\
2.600 \mathrm{E}-05 \\
2.500 \mathrm{E}-05 \\
1.200 \mathrm{E}-05 \\
4.400 \mathrm{E}-08 \\
1.900 \mathrm{E}-04\end{array}$ & $0.000 \mathrm{E}+00$ & $4.550 \mathrm{E}+04$ \\
\hline CONTAMINANT & & $\begin{array}{r}\text { AQUIFER } \\
\text { SORPTION }\end{array}$ & $\begin{array}{c}\text { AQUIFER } \\
\text { RETARDATION }\end{array}$ & $\begin{array}{l}\text { VERTICAL } \\
\text { SORPTION }\end{array}$ & $\begin{array}{l}\text { VERTICAL } \\
\text { RETARDATION }\end{array}$ \\
\hline Lead & & $2.700 \mathrm{E}+02$ & $1.030 \mathrm{E}+03$ & $2.700 \mathrm{E}+02$ & $1.620 \mathrm{E}+03$ \\
\hline CONTAMINANT & & $\begin{array}{c}\text { SOIL-PLANT } \\
\text { BV }\end{array}$ & $\begin{array}{c}\text { BIOACCUMUL } \\
\text { SOIL-PLANT } \\
\text { Br }\end{array}$ & $\begin{array}{c}\text { ION FACTORS } \\
\text { FORAGE-MILK } \\
\text { Fm (D/L) }\end{array}$ & $\begin{array}{c}\text { FORAGE-MEAT } \\
\text { Ff }(\mathrm{D} / \mathrm{KG})\end{array}$ \\
\hline Lead & & $6.800 \mathrm{E}-02$ & $6.800 \mathrm{E}-03$ & $6.200 \mathrm{E}-04$ & $2.900 \mathrm{E}-04$ \\
\hline
\end{tabular}

$\star * * * *$ PEAK CONCENTRATIONS AND
$\star * * * *$ WELL AT $1.0 \mathrm{M} * \star * * *$

FRACTION

CONTAMINANT

OF ADI

Lead
$1.25 \mathrm{E}+02$

$\begin{array}{cc}\text { PEAK } & \\ \text { CONCENTRATION } & \text { PEAK TIME } \\ (\mathrm{MG} / \mathrm{L}) & (\mathrm{YR})\end{array}$

AVERAGE DOSE AT PEAK TIME

(MG/KG-DAY)

AVERAGE RISK AT PEAK TIME

(HE/LIFE)

$1.83 \mathrm{E}+00$

25911.

$5.23 \mathrm{E}-02$

$0.00 \mathrm{E}+00$ 


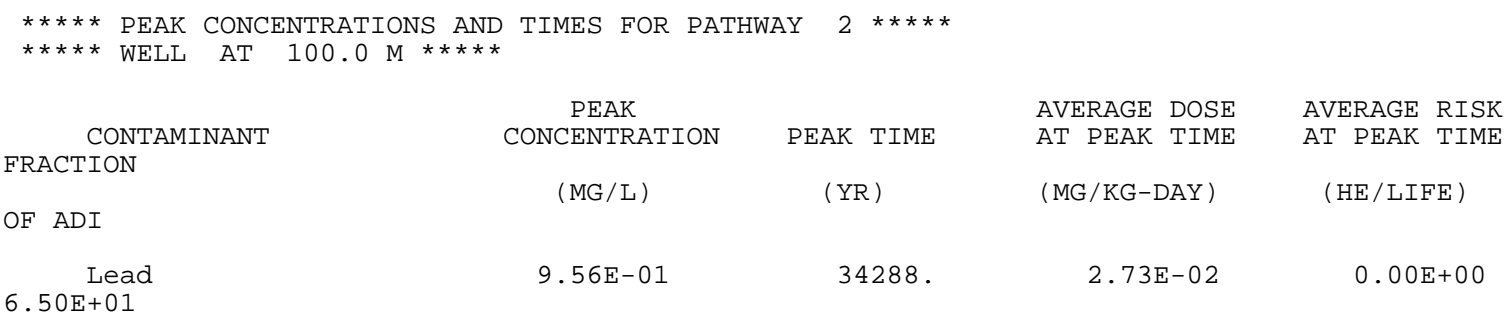


RESIDUAL SOIL SATURATION

PERMEABILITY OF VERTICAL ZONE (M/YR)

SOIL NUMBER

POROSITY OF AOUIFER

POROSITY OF UNSATURATED ZONE

DISTANCE FROM AQUIFER TO WASTE (M)

AVERAGE VERTICAL GROUNDWATER VELOCITY (M/YR)

HORIZONTAL VELOCITY OF AQUIFER (M/YR)

LENGTH OF PERFORATED WELL CASING (M)

SURFACE EROSION RATE (M/YR)

LEACH RATE SCALING FACTOR

ANNUAL RUNOFF OF PRECIPITATION (M)
.100

3.20

.250

.42

.42

8.0

$1.50 \mathrm{E}+00$

$1.00 \mathrm{E}+01$

6.000

$2.000 \mathrm{E}-03$

$1.000 \mathrm{E}+00$

$4.00 \mathrm{E}-01$

\begin{tabular}{|c|c|c|c|c|c|}
\hline CONTAMINANT & & $\begin{array}{c}\text { UNIT RISK } \\
\text { FACTORS } \\
\text { (KG-DAY/MG) }\end{array}$ & $\begin{array}{c}\text { ALLOWABLE DAILY } \\
\text { INTAKES } \\
\text { (MG/KG-DAY) }\end{array}$ & $\begin{array}{c}\text { HALF } \\
\text { LIFE (YR) }\end{array}$ & \\
\hline Lead & & $0.000 \mathrm{E}+00$ & $4.200 \mathrm{E}-04$ & $1.000 \mathrm{E}+10$ & \\
\hline CONTAMINANT & & $\begin{array}{l}\text { VOLATILITY } \\
\text { FRACTION }\end{array}$ & $\begin{array}{c}\text { VAPORIZATION } \\
\text { RATE } \\
(1 / S)\end{array}$ & $\begin{array}{c}\text { SKIN } \\
\text { ABSORPTION } \\
(\mathrm{M} / \mathrm{HR})\end{array}$ & \\
\hline Lead & & $0.000 \mathrm{E}+00$ & $0.000 \mathrm{E}+00$ & $0.000 \mathrm{E}+00$ & \\
\hline CONTAMINANT & SEG & $\begin{array}{c}\text { SEGMENT START } \\
(\mathrm{YR})\end{array}$ & $\begin{array}{c}\text { WASTE } \\
\text { DIFFUSION } \\
\text { COEF. }(\text { CM2/S })\end{array}$ & $\begin{array}{c}\text { CONCRETE } \\
\text { DIFFUSION } \\
\text { COEF. } \quad(\text { CM2 } / \mathrm{S})\end{array}$ & \\
\hline $\begin{array}{l}\text { Lead } \\
\text { Lead } \\
\text { Lead } \\
\text { Lead } \\
\text { Lead } \\
\text { Lead } \\
\text { Lead } \\
\text { Lead }\end{array}$ & $\begin{array}{l}1 \\
2 \\
3 \\
4 \\
5 \\
6 \\
7 \\
8\end{array}$ & $\begin{array}{l}0.000 \mathrm{E}+00 \\
2.500 \mathrm{E}+01 \\
2.000 \mathrm{E}+02 \\
3.000 \mathrm{E}+02 \\
5.000 \mathrm{E}+02 \\
1.000 \mathrm{E}+03 \\
2.500 \mathrm{E}+03 \\
1.200 \mathrm{E}+04\end{array}$ & & & \\
\hline CONTAMINANT & SEG & $\begin{array}{l}\text { INPUT LEACH } \\
\quad(1 / \text { YR })\end{array}$ & $\begin{array}{l}\text { FINAL LEACH } \\
(1 / \text { YR })\end{array}$ & $\begin{array}{c}\text { SOLUBILITY } \\
(\mathrm{MG} / \mathrm{L})\end{array}$ & $\begin{array}{c}\text { INITIAL } \\
\text { INVENTORY } \\
(\mathrm{KG})\end{array}$ \\
\hline $\begin{array}{l}\text { Lead } \\
\text { Lead } \\
\text { Lead } \\
\text { Lead } \\
\text { Lead } \\
\text { Lead } \\
\text { Lead } \\
\text { Lead }\end{array}$ & $\begin{array}{l}1 \\
2 \\
3 \\
4 \\
5 \\
6 \\
7 \\
8\end{array}$ & $\begin{array}{l}4.000 \mathrm{E}-05 \\
1.000 \mathrm{E}-05 \\
1.000 \mathrm{E}-05 \\
2.600 \mathrm{E}-05 \\
2.500 \mathrm{E}-05 \\
1.200 \mathrm{E}-05 \\
4.400 \mathrm{E}-08 \\
1.900 \mathrm{E}-04\end{array}$ & $\begin{array}{l}4.000 \mathrm{E}-05 \\
1.000 \mathrm{E}-05 \\
1.000 \mathrm{E}-05 \\
2.600 \mathrm{E}-05 \\
2.500 \mathrm{E}-05 \\
1.200 \mathrm{E}-05 \\
4.400 \mathrm{E}-08 \\
1.900 \mathrm{E}-04\end{array}$ & $0.000 \mathrm{E}+00$ & $4.550 \mathrm{E}+04$ \\
\hline CONTAMINANT & & $\begin{array}{r}\text { AQUIFER } \\
\text { SORPTION }\end{array}$ & $\begin{array}{c}\text { AQUIFER } \\
\text { RETARDATION }\end{array}$ & $\begin{array}{l}\text { VERTICAL } \\
\text { SORPTION }\end{array}$ & $\begin{array}{c}\text { VERTICAL } \\
\text { RETARDATION }\end{array}$ \\
\hline Lead & & $2.700 \mathrm{E}+02$ & $1.030 \mathrm{E}+03$ & $2.700 \mathrm{E}+02$ & $1.620 \mathrm{E}+03$ \\
\hline CONTAMINANT & & $\begin{array}{c}\text { SOIL-PLANT } \\
\text { BV }\end{array}$ & $\begin{array}{l}\text { BIOACCUMULAT } \\
\text { SOIL-PLANT } \\
\text { Br }\end{array}$ & $\begin{array}{l}\text { ION FACTORS } \\
\text { FORAGE-MILK } \\
\text { Fm (D/L) }\end{array}$ & $\begin{array}{l}\text { FORAGE-MEAT } \\
\text { Ff (D/KG) }\end{array}$ \\
\hline Lead & & $6.800 \mathrm{E}-02$ & $6.800 \mathrm{E}-03$ & $6.200 \mathrm{E}-04$ & $2.900 \mathrm{E}-04$ \\
\hline
\end{tabular}

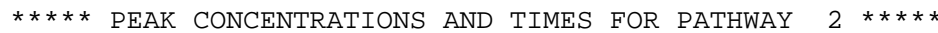

$\star * * * *$ WELL AT $1.0 \mathrm{M} * * * * *$

FRACTION

CONTAMINANT

OF ADI

Lead
$1.25 \mathrm{E}+02$

$$
\text { PEAK }
$$

CONCENTRATION PEAK TIME

(MG /L)

(YR)

25911 .

1. $83 \mathrm{E}+00$

AVERAGE DOSE AT PEAK TIME

(MG/KG-DAY)

AVERAGE RISK

AT PEAK TIME

(HE/LIFE) 


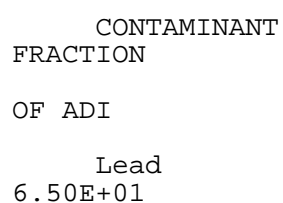

34288 .

AVERAGE DOSE

AT PEAK TIME

(MG/KG-DAY)

2. $73 E-02$
AVERAGE RISK

AT PEAK TIME

(HE/LIFE)

$0.00 \mathrm{E}+00$ 